\title{
Physiological quality of fennel (Foeniculum vulgare Miller) seeds stored in different containers and environmental conditions ${ }^{1}$
}

\author{
Raquel Fialho Rubim ${ }^{2 *}$, Silvério de Paiva Freitas ${ }^{2}$, \\ Henrique Duarte Vieira ${ }^{2}$, Geraldo de Amaral Gravina ${ }^{3}$
}

\begin{abstract}
For an adequate conservation of seeds it is essential previously establishing the ideal conditions for their storage. Thereby, this study aimed at evaluating influence of packaging types and storage environmental conditions on physiological quality of fennel seeds. The seeds were stored into three different packaging types (cotton bags, multiwall paper bags, and glass containers), and stored under two environmental conditions (laboratory and cold chamber) during a twelve months period. Physiological seed quality was assessed before storage and at every two months after storage through tests of germination, germination speed index, and electrical conductivity. Experiment was performed on a completely randomized design with treatments arranged in a split-split plot arrangement in time (two environmental storage conditions $\mathrm{x}$ three packaging types $\mathrm{x}$ six storage periods + a control treatment), with four replications. Fennel seeds packaged into glass containers have maintained their physiological quality stable over the twelve storage months regardless storage environmental conditions; being considered the best container for storing fennel seeds; and cotton packaging was considered as the least efficient for both storage under laboratory environmental conditions as well as for storage under cold chamber conditions.
\end{abstract}

Index terms: Foeniculum vulgare Miller, germination, vigor.

\section{Qualidade fisiológica de sementes de erva doce armazenadas em diferentes embalagens e condições ambientais}

\begin{abstract}
RESUMO - Para a conservação adequada das sementes é fundamental estabelecer, previamente, as condições ideais para o seu armazenamento. Sendo assim, o objetivo deste estudo foi avaliar a influência do tipo de embalagem e das condições ambientais de armazenamento na qualidade fisiológica de sementes de erva-doce. Para isso, sementes desta planta foram acondicionadas em três diferentes tipos de embalagem (algodão, papel multifoliado e vidro) e armazenadas sob duas condições ambientais (laboratório e câmara fria) durante doze meses. A qualidade fisiológica das sementes foi avaliada antes do armazenamento e a cada dois meses após, por meio dos testes de: germinação; índice de velocidade de germinação e condutividade elétrica. $\mathrm{O}$ experimento foi instalado em delineamento experimental inteiramente casualizado, com os tratamentos dispostos em esquema de parcelas sub-subdivididas no tempo (duas condições ambientais $\mathrm{x}$ três tipos de embalagens $\mathrm{x}$ seis períodos de armazenamento + uma testemunha), com quatro repetições. As sementes acondicionadas em embalagem de vidro mantiveram a sua qualidade fisiológica estável, durante os doze meses de armazenamento, independentemente das condições ambientais, sendo considerado o melhor recipiente; e a embalagem de algodão foi considerada a menos eficiente para o armazenamento, tanto em condições ambientais de laboratório quanto em condições ambientais de câmara fria.
\end{abstract}

Termos para indexação: Foeniculum vulgare Miller, germinação, vigor.

\section{Introduction}

The medicinal Eurasian sweet fennel plant (Foeniculum vulgare Miller) is also known as fennel, fake anise, or sweet anise, and is widely grown throughout Brazil. The species presents yellow flowers arranged in umbels bearing schizocarps

${ }^{1}$ Submitted on 05/11/2012. Accepted for publication on 04/24/2013.

${ }^{2}$ Laboratório de Fitotecnia, UENF, 28013-602 - Campos dos Goytacazes, RJ, Brasil. containing two akenes (Lorenzi and Matos, 2002). The plant possesses carminative, digestive and diuretic properties, its essential oil is used for manufacturing liqueurs and perfumes, and its seeds are widely used by the baking industry for aromatization of breads, cakes and cookies (Martins, 1999).

For being a plant with large medicinal and commercial

${ }^{3}$ Laboratório de Engenharia Agrícola, UENF, 28013-602 - Campos dos Goytacazes, RJ, Brasil.

*Corresponding author<raquel_rubim@yahoo.com.br> 
potential the use of seeds with high physiological potential is of fundamental importance on obtaining fennel crop fields with high productivity standards. However, despite the considerable increase on knowledge on medicinal species seeds generated by research in the last two decades for most of them are still needed more detailed information concerning preservation of physiological quality of its seeds during storage process.

To a safer and appropriate conservation of seeds it is essential knowing the environmental conditions in which these seeds will be stored; once the main factors influencing their physiological quality during storage (especially vigor) are the temperature and the storage environment relative humidity. The relative humidity directly affects moisture content of the seeds and controls the different metabolic processes, and the temperature influences speed of the biochemical processes; but despite indirectly it also interfere on seed moisture content (Marcos-Filho, 2005).

According to this same author, the packaging type used for storage is also very important on preserving the viability and vigor of seeds, once this factor may also affect the speed of biochemical processes related to seed deterioration. Within this context, Carvalho and Nakagawa (2000) state that on deciding the packaging type, it should be also considered other factors, such as: climatic conditions, under which these seeds will be stored until next crop season; mode of marketing; seed availability; and type of mechanical damages that these seeds may have undergone.

Lima et al. (2010) have found that seeds of Yellow Passion fruit (Passiflora edulis Sims) can be stored into hermetically sealed glass containers and kept into a refrigerator over a 120 days period, without affecting their physiological quality. Likewise, in studies performed on physiological quality of coriander (Coriandrum sativum L.) seeds, Nascimento et al. (2006) have packed seeds of such species in cardboard boxes (semipermeable packaging) and in aluminum foil bags (impermeable packaging) under controlled environmental conditions of cold chamber $\left(10{ }^{\circ} \mathrm{C} ; 45 \% \mathrm{RH}\right)$ and under laboratory environmental conditions; and verified that these seeds have maintained their physiological quality over one year storage, regardless environmental conditions in which they were stored.

In Brazil, the cultivation of medicinal plants has increased much nowadays; however, studies aiming at comparing storage methods, able on maintaining physiological quality of seeds of these species are virtually nonexistent.

Facing the foregoing, this study aimed at evaluating physiological quality of fennel seeds packed into different packaging types and stored under different environmental conditions over a twelve month period.

\section{Material and Methods}

The experiment was carried out at the Sector of Weeds and Medicinal Plants of the Center for Agricultural Sciences and Technologies of the State University of Northern Rio de Janeiro Darcy Ribeiro, located in municipality of Campos dos Goytacazes, State of Rio de Janeiro, Brasil.

Seeds used in the experiment were produced in a fennel commercial cultivation, located in the municipality of Simão Dias, Sergipe State, Northeast Region of Brasil (10 44' 29"; $37^{\circ} 48^{\prime} 36^{\prime \prime} \mathrm{W} ; 257 \mathrm{~m}$ altitude). Initial seed moisture content was determined on two seed samples of $4.5 \pm 0.5$ grams each, according to Rules for Seed Testing (Brasil, 2009) by using only those seeds containing initial moisture content of approximately $10 \%$ in wet basis.

The experiment was carried out in a completely randomized design with four replications. To constitute the treatments, fennel seeds were placed into three different types of packaging: cotton bags (CB), multiwall paper bags (MPB), and glass containers (GC) (all with $200 \mathrm{~g}$ capacity); and stored under laboratory environmental conditions and under controlled environmental conditions of cold chamber, set to temperature of $15.7{ }^{\circ} \mathrm{C}, 60 \%$ relative humidity over a twelve months period. Physiological quality of fennel seeds has been assessed in seven different storage periods, i.e., one assessment performed before storage (control), and six assessments performed with bimonthly intervals within the subsequent twelve months storage period. Seeds were assessed through the following tests:

Moisture content: was determined by the oven method $\left(105 \pm 3{ }^{\circ} \mathrm{C}\right.$, for $\left.24 \mathrm{~h}\right)$ according to Rules for Seed Testing (Brasil, 2009) by using four samples of $4.5 \pm 0.5 \mathrm{~g}$ seeds each, for each treatment. Results were expressed in percentage moisture content in wet basis.

Germination: four replications of 50 seeds each, for each treatment, were used. The seeds were evenly distributed upon two sheets of Germitest ${ }^{\circledR}$ paper moistened with sterile distilled water at a ratio of 2.5 times the dry substrate mass, covered with another sheet of the same paper likewise moistened, and immediately after the set (seeds + paper) was made into a roll. These rolls were then placed into a seed germinator, which was set to alternating temperatures ranging from $20^{\circ} \mathrm{C}$ to $30^{\circ} \mathrm{C}$, and photoperiod of $16 / 8 \mathrm{~h}(\mathrm{~L} / \mathrm{D})$. The assessment of percent germination was performed on the fourteenth day after test start, and conducted according to Rules for Seed Testing (Brasil, 2009). Results were expressed as percentage of normal seedlings emerged.

Emergence speed index (ESI): this test was carried out together with germination test. However, assessments were 
daily performed starting from the first day in which the seeds have shown protrusion of rootlet until final counting date of germination test; and computation of ESI was performed using equation proposed by Maguire (1962).

Electrical conductivity: four replications of 50 seeds each, for each treatment, were placed in plastic cups with $200 \mathrm{~mL}$ capacity each, covered with $75 \mathrm{~mL}$ of distilled water, and kept in a BOD incubator, at $25^{\circ} \mathrm{C}$, for a period of $24 \mathrm{~h}$ (Vieira and Carvalho, 1994). After such period, the electrical conductivity of imbibition solution was performed with aid of conductivimeter (brand HANNA Instruments, model HI8820N) and results were expressed in $\mu \mathrm{S} . \mathrm{cm}^{-1} \cdot \mathrm{g}^{-1}$.

Statistical analysis: the completely randomized design has been used with the treatments arranged in a split-split plot arrangement in time (two storage conditions $\mathrm{x}$ three packaging types $\mathrm{x}$ six storage periods + a control treatment), with four replications, where the plots were constituted by the two storage environmental conditions (laboratory and cold chamber), the subplots were constituted by the three packaging types (CB, $\mathrm{MPB}$, and GC), and the subsubplots were constituted by the six storage periods (2, 4, 6, 8, 10, and 12 months), and an additional treatment (before storage) that was used as control treatment. Results obtained were then subjected to the exploratory analyzes to assess assumptions of normality of residuals, homogeneity of variance of treatments, and additivity of model before being submitted to ANOVA. Means obtained for physiological quality of seeds stored in the three different types of packaging, within each storage condition were compared by Tukey test, at $5 \%$ probability; and means obtained for the different storage periods were compare by regression analysis.

\section{Results and Discussion}

The sources of variation were significant at $1 \%$ probability for all parameters assessed (germination, GSI, and electrical conductivity). Monthly mean temperature, as well as monthly mean relative humidity, which have occurred in the laboratory environmental conditions throughout all experimental period (January/2011 to January/2012), are presented on Table 1. As it may be observed in that table, average monthly temperature has ranged from $28.6{ }^{\circ} \mathrm{C}$ (February/2011) to $21.6{ }^{\circ} \mathrm{C}$ (July/2011) and relative humidity has ranged from $69 \%$ (September/2011) to $80 \%$ (December / 2011). Moisture content values obtained for the seeds packed in the three packaging types ( $\mathrm{CB}, \mathrm{MPB}$, and $\mathrm{GC})$, and stored under the two environmental conditions (laboratory and cold chamber) during 12 months, are shown on Table 2. Variation in seed moisture content was possibly due to occurrence of higher humidity in storage conditions, since relative humidity in the months of March and December/2011 and January/2012 were higher than in other periods assessed (Table 1).

Table 1. Monthly means of temperature and relative humidity recorded laboratory environmental conditions during 12 months storage of fennel seeds.

\begin{tabular}{lcc}
\hline \multicolumn{1}{c}{ Months } & Temperature $\left({ }^{\circ} \mathrm{C}\right)$ & Relative humidity $(\%)$ \\
\hline January/2011 & 27.7 & 76 \\
February & 28.6 & 73 \\
March & 26.1 & 80 \\
April & 25.8 & 77 \\
May & 22.9 & 75 \\
June & 22.9 & 73 \\
July & 21.6 & 72 \\
August & 22.9 & 73 \\
September & 22.6 & 69 \\
October & 24.2 & 78 \\
November & 24.2 & 78 \\
December & 25.8 & 80 \\
January/2012 & 26.1 & 79 \\
\hline
\end{tabular}

Table 2. Mean of values (\%) of moisture content of fennel seeds, packed into three packaging types, and stored under two environmental conditions (laboratory and cold chamber), during 12 months storage.

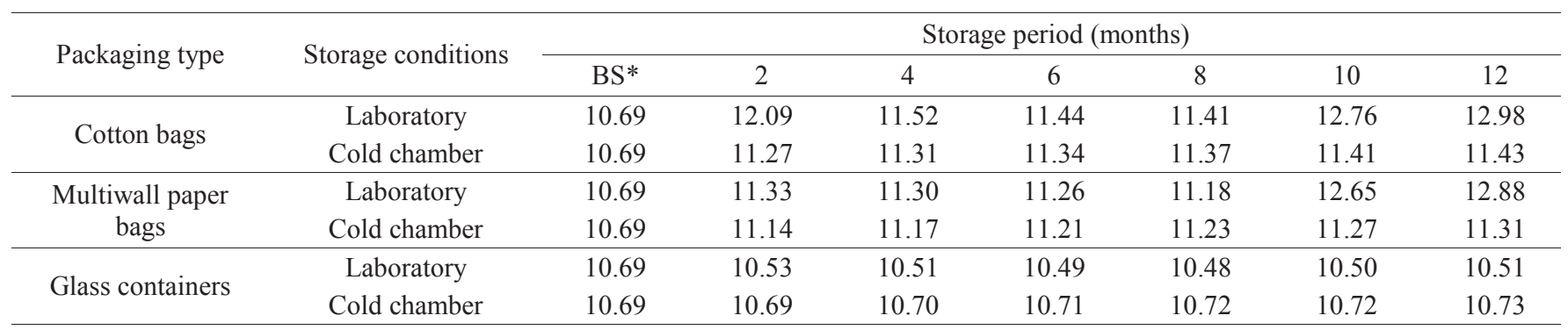

*BS $=$ before storage (control). 
Similar results were found by Torres et al., (2002), who working with gherkin seeds (Cucumis anguria L.) packed into three different packaging types (plastic bags, paper bags, and plastic boxes) and stored under laboratory environmental conditions for 12 months, have also observed that seed moisture content was higher on months in which relative humidity was likewise the highest.

When stored under laboratory environmental conditions as well as under environmental conditions of cold chamber, both into cotton packaging as into multiwall paper packaging, the fennel seeds have shown a small increase on initial moisture content when compared to moisture content of seeds evaluated in the other storage periods (Table 2). However, into the glass packaging, the seed moisture content was practically the same throughout all storage period (Table 2).

Similar results were observed by Souza et al., (2009) in seeds of sorghum (Sorghum bicolor (L.) Moench.), packed in multiwall paper bags and stored under controlled environmental conditions $\left(10{ }^{\circ} \mathrm{C}\right.$ and $\left.50 \% \mathrm{RH}\right)$, which have presented linear increase of moisture content (from $10 \%$ to $12 \%$ ) after a 28 months storage period.

The mean results obtained for germination, germination speed index, and electrical conductivity of fennel seeds assessed before storage are presented on Table 3. As it may be observed in this table, data show the seeds were presenting high viability before storage, with mean germination of $89 \%$, GSI of 39.69, and EC of $105.48 \mu \mathrm{S} \cdot \mathrm{cm}^{-1} \cdot \mathrm{g}^{-1}$.

Table 3. Means of values obtained to germination $(\mathrm{G})$, germination speed index (GSI), and electrical conductivity (EC) of fennel seeds assessed before storage.

\begin{tabular}{ccc}
\hline $\mathrm{G}(\%)$ & GSI & $\mathrm{EC}\left(\mu \mathrm{S} \cdot \mathrm{cm}^{-1} \cdot \mathrm{g}^{-1}\right)$ \\
\hline 89.00 & 39.69 & 105.48 \\
\hline
\end{tabular}

Percent germination of fennel seeds stored under both environmental conditions in the three different package types, and computed as function of storage period are plotted by the linear regression curves obtained for this parameter, and are shown on Figures 1 and 2. By observing the linear regression curve computed for the environmental laboratory conditions shown on Table 1, it is verifiable that best treatment was the one in which seeds were stored in the GC package; since in such treatment the germination was maintained above $80 \%$ throughout all the storage period assessed. Seeds stored in the MPB and CB packages have had their germination decreased throughout the storage period, whereas for seeds stored in the CB package this decrease was more pronounced, reaching value of $20.50 \%$ germination at the assessment performed (Figure 1; Table 4).

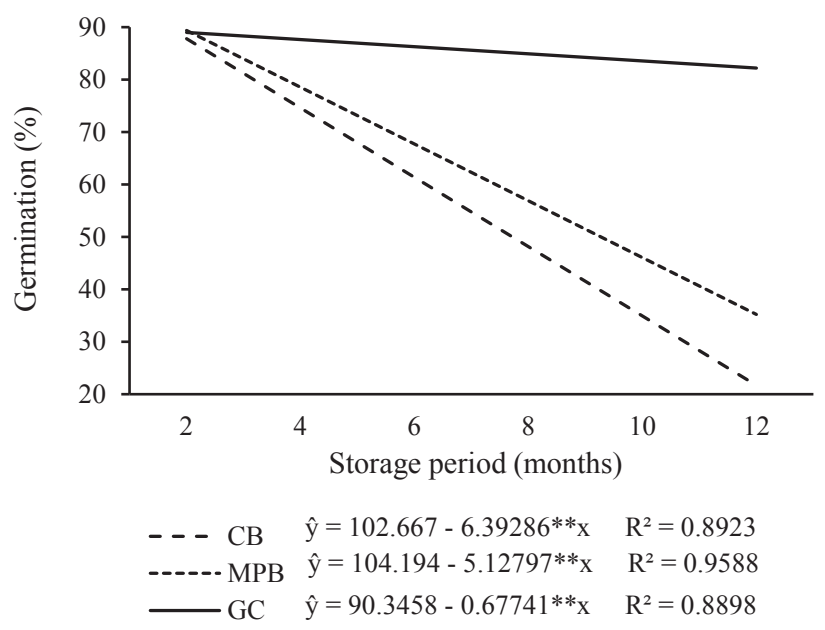

Figure 1. Linear regression curves plotted to germination percentage of fennel seeds packed in cotton bags (CB), multiwall paper bags (MPB), and glass containers (GC), and stored under laboratory environmental conditions, as function of storage period.

Table 4. Means of values obtained to germination percentage of fennel seeds packed into cotton bags (CB), multiwall paper bags (MPB) and glass containers (GC), stored under two environmental conditions (laboratory and cold chamber), during 12 months storage.

\begin{tabular}{|c|c|c|c|c|c|c|}
\hline \multirow{2}{*}{ Package type } & \multicolumn{6}{|c|}{ Storage period (months) } \\
\hline & 2 & 4 & 6 & 8 & 10 & 12 \\
\hline & \multicolumn{6}{|c|}{ Laboratory } \\
\hline MPB & $86.05 \mathrm{~A}$ & $85.00 \mathrm{~A}$ & $79.25 \mathrm{AB}$ & $72.00 \mathrm{~B}$ & $52.00 \mathrm{~B}$ & $35.50 \mathrm{~B}$ \\
\hline \multirow[t]{2}{*}{ GC } & $88.20 \mathrm{~A}$ & $87.50 \mathrm{~A}$ & $86.93 \mathrm{~A}$ & $86.00 \mathrm{~A}$ & $83.00 \mathrm{~A}$ & $81.00 \mathrm{~A}$ \\
\hline & \multicolumn{6}{|c|}{ Cold chamber } \\
\hline MPB & $88.41 \mathrm{~A}$ & $87.00 \mathrm{~A}$ & $86.50 \mathrm{~A}$ & $85.25 \mathrm{~A}$ & $83.00 \mathrm{~A}$ & $76.20 \mathrm{~A}$ \\
\hline GC & $88.71 \mathrm{~A}$ & $88.50 \mathrm{~A}$ & $88.22 \mathrm{~A}$ & $87.25 \mathrm{~A}$ & $86.00 \mathrm{~A}$ & $83.50 \mathrm{~A}$ \\
\hline
\end{tabular}

*Means followed by same letters in the columns do not statistically differ between each other by Tukey test, at $5 \%$ probability. 
Under cold chamber environmental conditions, seed germination percentage has also decreased with increasing storage period, regardless packaging used. Similar to what was found under laboratory environmental conditions the fennel seeds stored in the GC packages have maintained germination percentage above $80 \%$ during all 12 months storage period (Figure 2). However, the seeds stored in MPB and $\mathrm{CB}$ packages have shown higher germination percentage under these controlled environmental conditions with values to germination percentage above $75 \%$; what was far higher than values found under the laboratory environmental conditions (Figures 1 and 2).

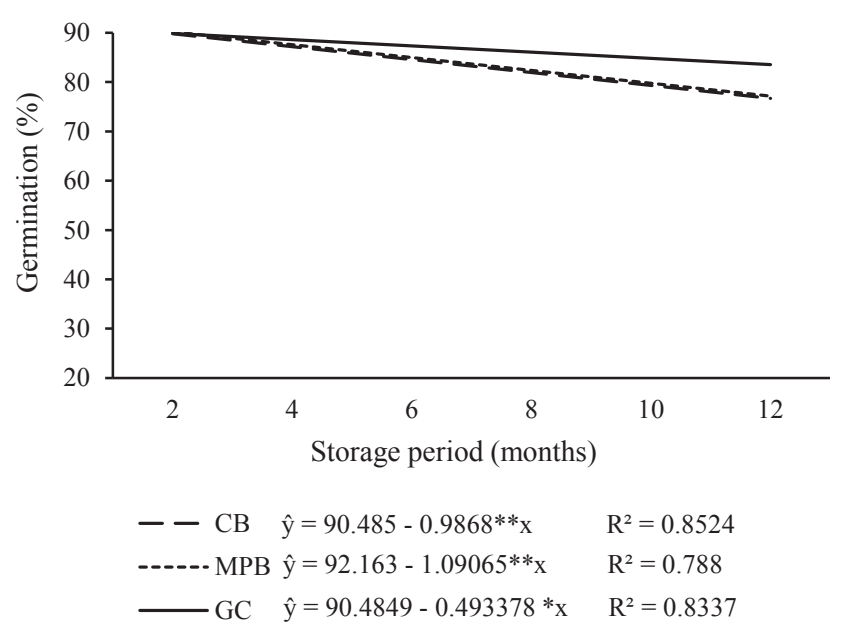

Figure 2. Linear regression curves plotted to germination percentage of fennel seeds packed in cotton bags $(\mathrm{CB})$, multiwall paper bags (MPB), and glass containers (GC), and stored under cold chamber environmental conditions, as function of storage period.

Results similar to those found in this study were obtained by Catunda et al. (2003), who working with seeds yellow Passion fruit, with $10 \%$ initial moisture content, stored under laboratory environmental conditions, and packed in multiwall paper packaging have also observed reduction on germination of these seeds over a 10 months storage period.

Bezerra et al. (2004) have also found that seeds of Drumstick (Moringa oleifera Lam), packed into recycled plastic bottles of polyethylene teraphthalate (PET) have kept the same germination percentage when stored under controlled environmental conditions of cold chamber during a 12 months storage period. However, when stored in laboratory under natural environmental conditions during this same period, germination of these seeds was reduced by $78 \%$.

As it may be observed on Table 4, mean values obtained for germination of fennel seeds stored under laboratory environmental conditions packed into $\mathrm{GC}$ have maintained their germination percentage above $80 \%$ throughout all 12 months of storage period. However, for seeds packed into MPB, the means for seed germination percentage obtained before the storage were statistically similar to the percent germination mean only until the second storage period studied (month 4) (Tables 3 and 4). Nevertheless, for seeds stored into $\mathrm{CB}$ this same behavior has been observed only until first storage period (month 2) (Table 4). Despite a slight reduction on percent germination detected only in the sixth assessment period (month 12), and regardless type of packaging used for storage, when seeds were stored under cold chamber environmental conditions they have maintained their germination percentage statistically similar (Table 4).

Within this context, Batista et al. (2011) have observed that seeds of Cedar tree (Cedrela fissilis Vell.) packed into plastic bags and $\mathrm{Kraft}^{\circledR}$ type paper bags, and stored under non-controlled environmental conditions have also presented a reduction on percent germination over the entire storage period studied.

These results demonstrate that the storage of fennel seeds under controlled environmental conditions of cold chamber contributes on reducing the speed of deterioration processes, thereby keeping their initial germination percentage during all 12 months of storing period studied, regardless the package used for storage; and corroborate the results obtained by Torres (2005), who has verified that seeds of watermelon (Citrullus lanatus (Thunb.) Matsum. \& Nakai) have maintained higher physiological quality when stored under controlled environmental conditions of cold chamber as compared to seeds stored under non-controlled environmental conditions during a 12 months storage period.

Linear regression curves plotted with mean values obtained to GSI are shown on Figures 3 and 4. As it may be observed on Figure 3, means obtained for the GSI of seeds packed into GC were higher than means obtained for seeds packed into $\mathrm{CB}$ and MPB, both under laboratory environmental conditions as cold chamber environmental conditions (Figures 3 and 4). The highest GSI reductions observed for seeds packed into GC and MPB were found for those seeds stored under laboratory environmental conditions (4.48 and 8.14, respectively); however, seeds stored into GC have maintained their GSI initial value statistically similar throughout the storage period (Figure 5). The lowest values obtained for the GSI of seeds packed in these two packaging types, and stored under cold chamber environmental conditions (23.37 and 25.60, respectively) were found at twelve months (Table 5). 


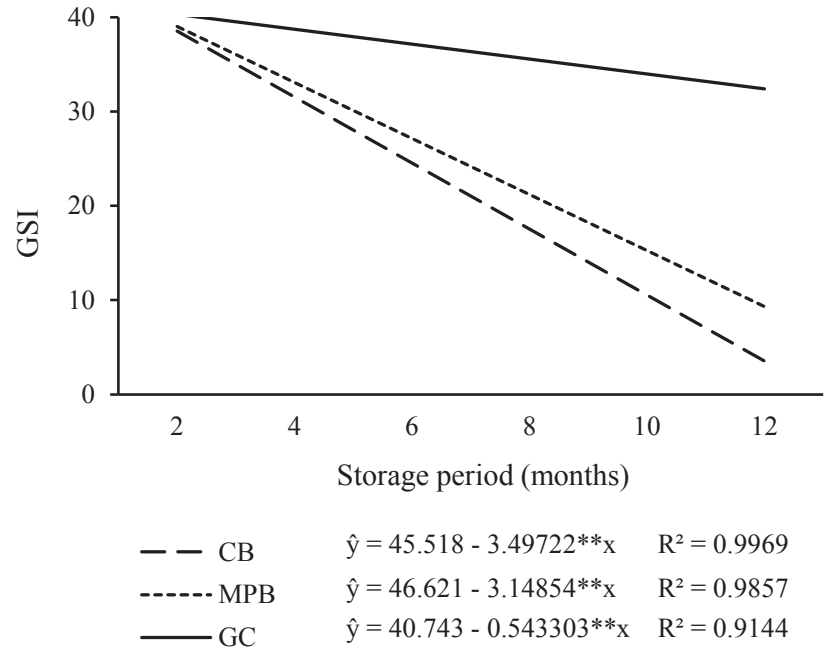

Figure 3. Linear regression curves plotted to germination speed index (GSI) of fennel seeds packed in cotton bags (CB), multiwall paper bags (MPB), and glass containers (GC), and stored under laboratory environmental conditions, as function of storage period.

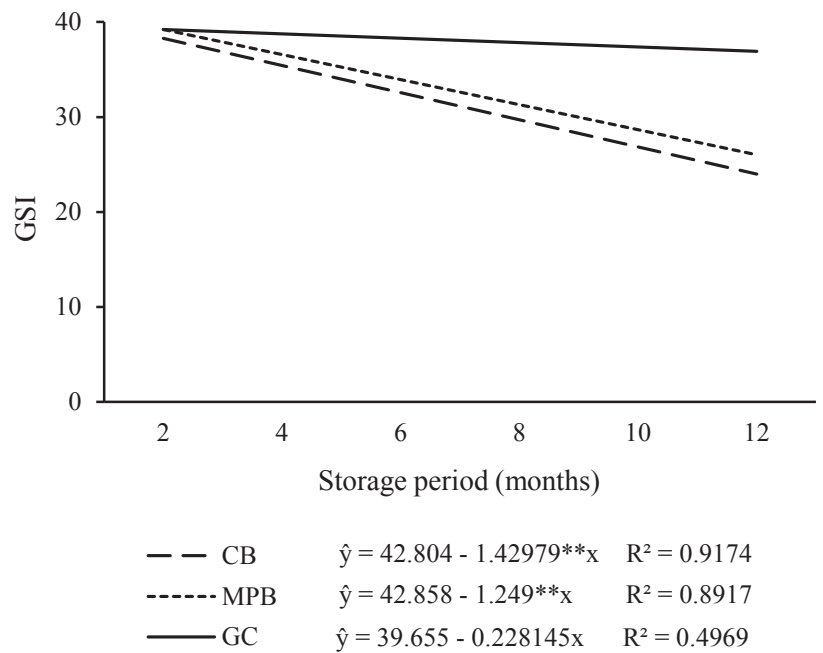

Figure 4. Linear regression curves plotted to germination speed index (GSI) of fennel seeds packed in cotton bags (CB), multiwall paper bags (MPB), and glass containers (GC), and stored under cold chamber environmental conditions, as function of storage period.

Table 5. Means of values obtained to germination speed index of fennel seeds packed into cotton bags (CB), multiwall paper bags (MPB), and glass containers (GC), stored under two environmental conditions (laboratory and cold chamber during 12 months storage.

\begin{tabular}{|c|c|c|c|c|c|c|}
\hline \multirow{2}{*}{ Package type } & \multicolumn{6}{|c|}{ Storage period (months) } \\
\hline & 2 & 4 & 6 & 8 & 10 & 12 \\
\hline & \multicolumn{6}{|c|}{ Laboratory } \\
\hline $\mathrm{CB}$ & $38.42 \mathrm{~A}^{*}$ & $32.09 \mathrm{~B}$ & $24.36 \mathrm{~B}$ & $17.52 \mathrm{~B}$ & $9.34 \mathrm{C}$ & $4.48 \mathrm{~B}$ \\
\hline MPB & $38.57 \mathrm{~A}$ & $35.65 \mathrm{AB}$ & $29.08 \mathrm{~B}$ & $20.19 \mathrm{~B}$ & $15.85 \mathrm{~B}$ & $8.14 \mathrm{~B}$ \\
\hline \multirow[t]{2}{*}{ GC } & $39.22 \mathrm{~A}$ & $38.26 \mathrm{~A}$ & $37.98 \mathrm{~A}$ & $37.36 \mathrm{~A}$ & $35.26 \mathrm{~A}$ & $33.54 \mathrm{~A}$ \\
\hline & \multicolumn{6}{|c|}{ Cold chamber } \\
\hline $\mathrm{CB}$ & $38.54 \mathrm{~A}$ & $36.70 \mathrm{~A}$ & $35.77 \mathrm{~A}$ & $32.75 \mathrm{~A}$ & $29.64 \mathrm{~B}$ & $23.37 \mathrm{~B}$ \\
\hline MPB & $39.32 \mathrm{~A}$ & $36.93 \mathrm{~A}$ & $37.13 \mathrm{~A}$ & $34.02 \mathrm{~A}$ & $31.68 \mathrm{AB}$ & $25.60 \mathrm{~B}$ \\
\hline $\mathrm{GC}$ & $39.36 \mathrm{~A}$ & $38.97 \mathrm{~A}$ & $38.03 \mathrm{~A}$ & $37.55 \mathrm{~A}$ & $36.00 \mathrm{~A}$ & $37.94 \mathrm{~A}$ \\
\hline
\end{tabular}

*Means followed by same letters in the columns do not statistically differ between each other by Tukey test, at $5 \%$ probability.

However, mean values obtained for GSI of seeds stored under cold chamber environmental conditions did not present statistically significant differences between the three types of packaging studied, until the fourth assessment period (month 8) (Table 5). Nevertheless, from this assessment, the GSI obtained to seeds packed into CB and MPB were lower than that of seeds packed in GC, which have maintained the GSI statistically similar throughout all studied period (Table 5).

Similar results were found by Zonta et al. (2010), who in a study performed with seeds of the evergreen tree loquat (Eriobotrya japonica (Thunb.) Lindl.) packed into polyethylene bags and Kraft ${ }^{\circledR}$ paper bag, and stored under laboratory environmental conditions have observed that GSI for seeds of this species was linearly reduced over a 180 days storage period. Linear regression curves, plotted to electrical conductivity values obtained for fennel seeds have shown a positive linear gradient throughout the storage period, both for seeds stored under laboratory environmental conditions as well as for seeds stored under cold chamber environmental conditions, regardless the packaging type used for storage. However, when seeds were packed into GC, the regression curve has peaked much lower than the peaks of regression curves plotted to the values obtained for the two other packaging types (Figures 5 and 6); thereby showing that when stored into this packaging type the seeds of fennel undergo less deterioration during extensive storage periods. 


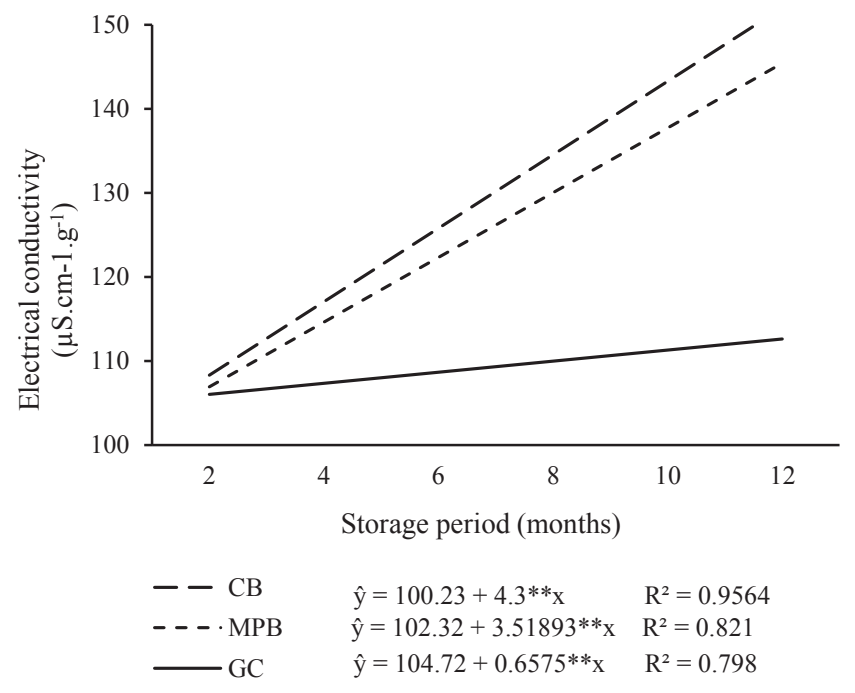

Figure 5. Linear regression curves plotted to electrical mean conductivity values obtained to fennel seeds packed in cotton bags (CB), multiwall paper bags (MPB), and glass containers (GC), and stored under environmental conditions of laboratory, as function of storage period.

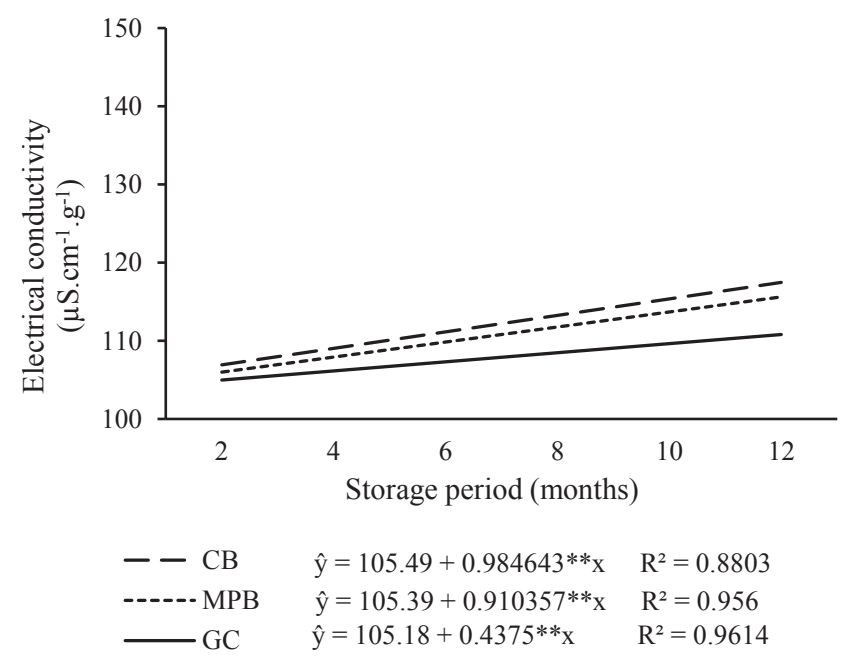

Figure 6. Linear regression curves plotted to electrical mean conductivity values obtained for fennel seeds packed into cotton bags (CB), multiwall paper bags (MPB), and glass containers (GC), and stored under cold chamber environmental conditions, as function of storage period.

Similar results were obtained by Oliveira et al. (2011), who working with seeds of corn (Zea mays L.) have verified that electric conductivity values increased over a 214 days storage period, when these seeds were packed into cotton bags and cardboard Tetra Pak ${ }^{\circledR}$ boxes and stored under non- controlled environmental conditions of temperature and relative humidity.

Likewise, Azeredo et al. (2005) have verified that the EC values obtained for peanut (Arachis hypogaea L.) seeds have remained constant throughout all storage period when these seeds were packed in $\mathrm{Kraft}{ }^{\circledR}$ paper bags and/or metallic containers, and stored under dry chamber environmental conditions. However, when seeds were packed in the metallic packaging and stored under laboratory environmental conditions the EC values have presented a linear gradient positive and increasing for this variable.

Pertel et al. (2008) have reported that coffee (Coffea arabica L.) seeds (cv. "Catuai vermelho" IAC 144 and Rubi MG 1192), when assessed by the EC test have had their physiological quality values (vigor) decreased with the increase in the storage period, and that such increase was linear and increasing over the storage period assessed.

By the means presented on Table 6 it may be observed, that under laboratory environmental conditions the mean values obtained by CE test for seeds stored into VD packaging were statistically lower than means obtained for the seeds stored in the other two packaging types only after the second assessment (month 4). However, to the seeds packed into CB and stored under cold chamber environmental conditions the mean values obtained for $\mathrm{CE}$ in the fourth and fifth assessment (months 8 and 10) were statistically similar to means obtained to the seeds packed into MPB, although statistically higher than means obtained for the seeds stored into GC (Table 6).

On analyzing separately each packaging type, it is possible perceiving that from the second assessment (month 4) seeds stored under laboratory environmental conditions have presented higher mean values for EC than those mean values obtained for seeds stored under cold chamber environmental conditions (Table 6).

According to Rech et al. (1999), these results may be explained by the fact that when subjected to EC test, the seeds with low vigor may present higher values for EC, mainly due to the greater amount of solutes leached from seeds to imbibition solution as a result of the integrity loss of cell membranes. Thereby, it is possible to infer that GC packages are the most suitable for storing fennel seeds during extensive storage periods, regardless the environmental conditions in which these seeds are stored.

Results herein obtained allow stating that GC is the most suitable for fennel seeds packaging, since in all storage periods assessed the mean of values obtained for the seeds stored in this type of packaging presented the best results in all tests performed, excepting the EC test, carried out on the fourth and the fifth assessment (months 
8 and 10) (Table 6), possibly for being an impermeable packing. Similar behavior has been also observed by Azevedo et al. (2003) who reported that viability of sesame
(Sesamum indicum L.) seeds have been maintained with high physiological quality for longer period when those seeds were packed into impermeable packaging.

Table 6. Means of values obtained for electric conductivity $\left(\mu \mathrm{S} . \mathrm{cm}^{-1} \cdot \mathrm{g}^{-1}\right)$ of fennel seeds, packed into cotton bags (CB), multiwall paper bags (MPB) and glass containers (GC), stored under two environmental conditions (laboratory and cold chamber) during 12 months storage.

\begin{tabular}{|c|c|c|c|c|c|c|}
\hline \multirow{2}{*}{ Package type } & \multicolumn{6}{|c|}{ Storage period (months) } \\
\hline & 2 & 4 & 6 & 8 & 10 & 12 \\
\hline & \multicolumn{6}{|c|}{ Laboratory } \\
\hline MPB & $106.60 \mathrm{~A}$ & $120.33 \mathrm{~A}$ & $126.13 \mathrm{~B}$ & $138.68 \mathrm{~A}$ & $141.13 \mathrm{~A}$ & $144.8 \mathrm{~B}$ \\
\hline \multirow[t]{2}{*}{ GC } & $106.33 \mathrm{~A}$ & $108.35 \mathrm{~B}$ & $108.68 \mathrm{C}$ & $109.48 \mathrm{~B}$ & $112.30 \mathrm{~B}$ & $112.0 \mathrm{C}$ \\
\hline & \multicolumn{6}{|c|}{ Cold chamber } \\
\hline MPB & $106.80 \mathrm{~A}$ & $108.45 \mathrm{~A}$ & $111.70 \mathrm{~A}$ & $113.60 \mathrm{AB}$ & $114.47 \mathrm{AB}$ & $115.5 \mathrm{~A}$ \\
\hline GC & $105.83 \mathrm{~A}$ & $107.50 \mathrm{~A}$ & $107.43 \mathrm{~A}$ & $108.65 \mathrm{~B}$ & $109.70 \mathrm{~B}$ & $110.0 \mathrm{~A}$ \\
\hline
\end{tabular}

*Means followed by the same letters in columns do not statistically differ between each other by Tukey test, at $5 \%$ probability

Moreover, the initial moisture content of the seeds may have also been of fundamental importance in the fennel seed conservation, once seeds stored into packages allowing gas exchange with atmospheric air (e.g. CB) (Table 2 ) may have absorbed more water from environment when stored under environmental conditions with greater relative humidity; thereby deteriorating more easily. However, when the seeds were stored under laboratory environmental conditions, they generally have had lower vigor than the seeds stored into the two other packaging types (Table 2).

\section{Conclusions}

Fennel seeds may be stored for a period of twelve months both under laboratory environmental conditions as cold chamber environmental conditions without losing their initial physiological quality when packaged into glass containers.

The laboratory environmental conditions as well as the cotton packaging or the multiwall paper packaging are not suitable to store fennel seeds during long storage periods.

\section{Acknowledgement}

To Foundation for Research Support of the State of Rio de Janeiro (FAPERJ) for financial support granted to this study.

\section{References}

AZEREDO, G.A.; BRUNO, R.L.A.; LOPES, K.P.; SILVA, A.; DINIZ, E.; LIMA, A.A. Conservação de sementes de amendoim (Arachis hypogaea L.) em função do beneficiamento, embalagem e ambiente de armazenamento. Pesquisa Agropecuária Tropical, v.35, n.1, p.37-44, 2005. http://www. revistas.ufg.br/index.php/pat/article/view/2284

AZEVEDO, M.R.Q.A.; GOUVEIA, J.P.G.; TROVÃO, D.M.M.; QUEIROGA, V.P. Influência das embalagens e condições de armazenamento no vigor de sementes de gergelim. Revista Brasileira de Engenharia Agrícola e Ambiental, v.7, n.3, p.519-524, 2003. http://www.scielo.br/pdf/\%0D/rbeaa/ v7n3/v7n3a19.pdf

BATISTA, I.M.P.; FIGUEIREDO, A.F.; SILVA, A.M.; SILVA, T.A.F. Efeito de embalagens, ambientes e períodos de armazenamento na germinação e no vigor das sementes de cedro (Cedrela odorata) em Manaus-AM. Floresta, v.41, n.4, p.809-818. 2011. http://ojs.c3sl.ufpr.br/ojs-2.2.4/index.php/floresta/ article/view/25345/16983

BEZERRA, A.M.E.; MEDEIROS FILHO, S.; FREITAS, J.B.S.; TEÓFILO, E.M. Avaliação da qualidade das sementes de Moringa oleifera LAM. durante o armazenamento. Ciência e Agrotecnologia, v.28, n.6, p.1240-1246, 2004. http://www.scielo.br/pdf/cagro/v28n6/a04v28n6.pdf

BRASIL. Ministério da Agricultura, Pecuária e Abastecimento. Regras para análise de sementes. Ministério da Agricultura, Pecuária e Abastecimento. Secretaria de Defesa Agropecuária. Brasília: MAPA/ACS, 2009. 395p. http:// www.bs.cca.ufsc.br/publicacoes/regras $\% 20$ analise $\% 20$ sementes.pdf

CARVALHO, N.M.; NAKAGAWA, J. Sementes: ciência, tecnologia e produção. 4.ed. Jaboticabal: FUNEP, 2000. 588p.

CATUNDA, P.H.A.; VIEIRA, H.D.; SILVA, R.F.; POSSE, S.C.P. Influência do teor de água, da embalagem e das condições de armazenamento na qualidade de sementes de maracujá amarelo. Revista Brasileira de Sementes, v.25, n.1, p.65-71, 2003. http://www.scielo.br/scielo.php?pid=S010131222003000100011\&script=sci_arttext

LIMA, P.O.; LIRA, L.M.; LOPES, K.P.; BARBOSA, R.C.A. Armazenamento de sementes de maracujá-amarelo. Revista Verde, v.5, n.5, p.102-109, 2010. http://www.gvaa.com.br/revista/index.php/RVADS/article/view/471

LORENZI, H.; MATOS, F.J.A. Plantas Medicinais do Brasil: nativas e exóticas. Nova Odessa, SP: Instituto Plantarum, 2002. 512p. 
MAGUIRE, J.D. Speed of germination-aid in selection and evolution for seedling emergence and vigor. Crop Science, v.2, n.2, p.176-177, 1962.

MARCOS-FILHO, J. Fisiologia de sementes de plantas cultivadas. Piracicaba: FEALQ, 2005. 495p.

MARTINS, S.R. Sustentabilidade na agricultura: dimensões econômicas, sociais e ambientais. Revista Cientifica Rural, v.4, n.2, p.175-187, 1999. http://www.urcamp.tche.br/rcrural

NASCIMENTO, W.M.; PEREIRA, R.S.; FREITAS, R.A.; BLUMER, L.; MUNIZ, M.F.B. Colheita e armazenamento de sementes de coentro. Pesquisa Agropecuária Brasileira, v.41, n.12, p.1793-1801, 2006. http://www.scielo. br/pdf/\%0D/pab/v41n12/a15v4112.pdf

OLIVEIRA, A.C.S.; COELHO, F.C.; VIEIRA, H.D.; RUBIM, R.F. Armazenamento de sementes de milho em embalagens reutilizáveis, sob dois ambientes. Revista Brasileira de Milho e Sorgo, v.10, n.1, p.17-28, 2011. http://rbms.cnpms.embrapa.br/index.php/ojs/article/viewArticle/334

PERTEL, J.; DIAS, D.C.F.S.; DIAS, L.A.S.; BORGES, E.E.L.; NAVEIRA, D.S.P. Qualidades fisiológica de sementes de café (Coffea arabica L.) durante o armazenamento. Revista Brasileira de Armazenamento, Especial Café, v.10, p.15-23, 2008.

RECH, E.G.; VILLELA, F.A.; TILLMANN, M.A.A. Avaliação rápida da qualidade fisiológica de sementes de ervilha. Revista Brasileira de Sementes, v.21, n.2, p.1-9, 1999. http://www.abrates.org.br/revista/artigos/1999/v21n2/ artigo01.pdf
SOUZA, G.F.M.V.; SANTOS, C.M.; SANTANA, D.G.; SÁ JÚNIOR, A. Armazenamento de sementes de sorgo submetidas a diferentes graus de umidade de colheita. Semina: Ciências Agrárias, v.30, n.4, p.745-752, 2009. http://www.uel.br/revistas/uel/index.php/semagrarias/article/view/4069

TORRES, S.B. Qualidade de sementes de melancia armazenadas em diferentes embalagens e ambientes. Ciência Agronômica, v.36, n.2, p.163168, 2005. http://www.ccarevista.ufc.br/seer/index.php/ccarevista/article/ view/263

TORRES, S.B.; SILVA, M.A.S.; RAMOS, S.R.; QUEIRÓZ, M.A. Qualidade de sementes de maxixe armazenadas em diferentes embalagens e ambientes. Ciência e Agrotecnologia, v.26, n.3, p.539-544, 2002. http://www.editora. ufla.br/_adm/upload/revista/26-3-2002_12.pdf

VIEIRA, R.D.; CARVALHO, M.N. Testes de vigor em sementes. Jaboticabal: FUNEP, 1994. 164p.

ZONTA, J.B.; SOUZA, L.T.; ZONTA, F.M.G.; ZONTA, J.H.; ARAÚJO, E.F.; ARAÚJO, R.F. Temperatura e embalagem na conservação de sementes de nêspera. Revista Brasileira de Armazenamento, v.35, n.2, p.91-98, 2010. 